\title{
REKONSTRUKSI FUNGSI PERS DALAM UNDANG-UNDANG NOMOR 40 TAHUN 1999 TERHADAP PENEGAKAN HUKUM TINDAK PIDANA KORUPSI DI INDONESIA BERBASIS NILAI KEADILAN
}

\author{
Agus Wibowo \\ Universitas Tujuh Belas Agustus (Untag) Semarang \\ Email: hajiaguswibowo@yahoo.com
}

\begin{abstract}
Corruption increasingly widespread, more systematic and more sophisticated. Corruption in this country is like a vicious circle that is difficult to eradicate. The corrupt one with the other criminals who help each other, work together and protect each other. Corruption as a phenomenon like "snowball", if the crimes of corruption committed by one or a group of people uncovered, then another group would come out anyway. Therefore, corruption is an extraordinary crime that eradication also requires extra effort. The role of mass media in the political framework of this criminal according to Hoefnagels aligned with political efforts criminals who else is Criminal Law Application (Practical Criminology), namely prevention crime by means of criminal law and Prevention Without Punishment namely the prevention of offenses through means outside the criminal law.
\end{abstract}

Keyword : the function of the press, the rule of corruption.

\begin{abstract}
ABSTRAK
Korupsi semakin lama semakin meluas, lebih sistematis dan lebih canggih. Korupsi di negeri ini bagaikan lingkaran setan yang sulit diberantas. Para koruptor yang satu dengan koruptor yang lainnya saling membantu, bekerja sama dan saling melindungi. Korupsi seperti ibarat fenomena "bola salju", jika kejahatan korupsi yang dilakukan oleh satu atau sekelompok orang terbongkar, maka kelompok lainnya akan terbongkar pula. Oleh karenanya, korupsi merupakan extraordinary crime sehingga pemberantasannyapun memerlukan upaya ekstra. Peranan media massa dalam kerangka politik kriminal ini menurut Hoefnagels disejajarkan dengan upaya-upaya politik kriminal yang lain yaitu Criminal Law Application (Practical Criminology) yaitu penanggulangan tindak pidana dengan sarana hukum pidana dan Prevention Without Punishment yaitu penanggulangan tindak pidana melalui sarana di luar hukum pidana.
\end{abstract}

Kata Kunci : Fungsi Pers, Penegakan Tindak Pidana Korupsi.

\section{A. Pendahuluan}

Konsekwensi logis dari luasnya wilayah perairan laut Indonesia tersebut, perairan Indonesia rawan terjadi pencurian ikan (illegal Fishing) oleh nelayan-nelayan asing. Data akibat praktik pencurian ikan tersebut (termasuk didalamnya adalah Illegal Fishing, Unreported Fishing, dan Unregulated Fishing/ IUU), Indonesia mengalami kerugian sekitar 30 Triliun rupiah pertahun. Suatu jumlah yang cukup besar, bahkan lebih besar dampak kerugian keuangan negara tersebut jika dibandingkan dengan tindak pidana korupsi sekalipun.
Tindak pidana dibidang perikanan juga tidak hanya masalah Illegal Fishing, Unreported Fishing, dan Unregulated Fishing saja, tetapi banyak jenisnya. Pengeboman ikan, penggunaan bahan beracun dan berbahaya, penggunaan alat tangkap ikan yang dilarang, pelanggaran terhadap fishing ground, transhipment, pemalsuan dokumen perikanan, pelanggaran dokumen kapal penangkap ikan dan pelanggaran kejahatan dibidang perikanan lainnya.

Deklarasi Indonesia atas Zona Ekonomi Ekslusif Indonesia selebar 200 mil 
laut pada tanggal 21 Maret 1980, telah pula menambah daftar kekayaan laut Indonesia. Kekayaan laut Indonesia yang melimpah ruah tersebut, perlu didukung dengan pengaturan, pengelolaan, pengawasan dan penegakan hukum yang baik. Keberadaan UndangUndang Nomor 45 Tahun 2009 Tentang Perubahan Atas Undang-Undang Nomor 31 Tahun 2004 Tentang Perikanan sebagai dasar regulasi tata kelola perikanan di Indonesia, secara komprehensif diarahkan untuk mampu mengatur, mengelola dan mengawasi serta melakukan penegakan hukum yang benar dan tegas dibidang perikanan.

Persoalan penegakan hukum di laut, khususnya menyangkut tindak pidana dibidang perikanan, mempunyai sisi penanganan yang berbeda, jika dibandingkan dengan penanganan tindak pidana lainnya, baik tindak pidana umum ${ }^{1}$, maupun tindak pidana khusus lainnya ${ }^{2}$. Penanganan tindak pidana perikanan, berlaku asas Lex Specialis derogate legi generalis.

Mengingat sifatnya yang khusus, Undang-undang Nomor 45 Tahun 2009 mempunyai aturan yang khusus pula dalam hal proses penyidikan, penuntutan dan persidangan di pengadilan perkara tindak pidana perikanan. Namun demikian, sesuai

1 Tindak pidana umum adalah tindak pidana yang dasar pengaturannya berdasarkan Kitab UndangUndang Hukum Pidana (KUHP). Sehingga dalam hal ini berlaku asas legalitas Nullum Delictum Nulla Poena Sine Praevia Lege Poenali (Suatu perbuatan tidak dapat dipidana, kecuali berdasarkan kekuatan ketentuan perundang-undangan pidana yang telah ada), sebagaimana diatur dalam ketentuan Pasal 1 ayat (1) KUHP.

2 http://kakpanda.blogspot.com/2012/12/tindakpidana-khusus.html : Tindak pidana khusus adalah Tindak Pidana yang didasarkan pada undang-undang pidana atau hukum pidana yang diatur dalam undang-undang pidana tersendiri. Pernyataan ini sesuai dengan pendapat Pompe yang mengatakan : " Hukum Pidana Khusus mempunyai tujuan dan fungsi tersendiri". Yang dimaksud undang-undangpidana adalah undangundang yang memuat atau mengatur perumusan tindak pidana, dan berlakunya ketentuann hukum pidana. Khusus untuk hukum tindak pidana khusus diharuskan adanya indikator penyimpangan terhadaphukum pidana materil dan juga formal. ketentuan Pasal 72, 74 dan 77 UndangUndang Nomor 45 Tahun 2009, Penyidikan, penuntutan dan pemeriksaan di sidang pengadilan dalam perkara tindak pidana di bidang perikanan, dilakukan berdasarkan hukum acara yang berlaku, kecuali ditentukan lain dalam Undang-Undang ini. Artinya, masih terbuka peluang untuk menggunakan Kitab Undang-Undang Hukum Acara Pidana (KUHAP), apabila undang-undang perikanan tidak mengaturnya.

Proses penyidikan dan penuntutan tindak pidana perikanan dalam hal-hal tertentu diatur secara khusus (lex specialis derogat legi generali) serta mengesampingkan hukum pidana formil yang bersifat umum (KUHAP), seperti masalah penyidikan, terkait kewenangan penyidik, penahanan dan penahanan lanjutan, masalah penuntutan terkait dengan syarat sebagai penuntut umum, batas waktu penelitian berkas perkara serta batas waktu pelimpahan perkara. Proses penyidikan dan penuntutan tindak pidana perikanan dilakukan untuk menegakan aturan hukum yang benar terhadap pelanggaran di bidang perikanan.

Secara nasional, pelanggaran/ tindak pidana dibidang perikanan menunjukan angka yang cukup signifikan. Ini berarti, perlu strategi khusus untuk menangani persoalan tindak pidana perikanan di Indonesia. Untuk lingkup lokal atau daerah, meskipun tindak pidana dibidang perikanan tidak sebanyak yang terjadi didaerah-daerah seperti kepulauan Natuna, Tual maupun Sorong, namun persoalan/konflik yang timbul antar nelayan maupun pelanggaran-pelanggaran atas alat tangkap maupun dokumen kapal perikanan, tidak boleh dibiarkan. Persoalan kecil semacam ini dapat menimbulkan masalah yang lebih besar dikemudian hari, apabila tidak ada penanganan yang serius dari aparat penegak hukum.

Strategi yang perlu diterapkan untuk penanganan masalah tindak pidana perikanan adalah dengan menyiapkan perangkat hukum yang lengkap, penegakan hukum yang tidak diskriminatif serta membangun kelembagaan pengawasan dari tingkat pusat 
hingga daerah. Masyarakat juga diminta aktif dalam mengawasi praktek illegal fishingdan tindak pidana perikanan lainnya.

Langkah lain yang dapat ditempuh adalah membentuk jaksa perikanan, membentuk pengadilan khusus perikanan beserta perangkat peradilannya serta pemberian sanksi yang keras kepada para pelaku, pemberian insentif kepada penegak hukum, selain juga harus meningkatkan jaringan kerjasama internasional.

Berdasarkan uraian latar belakang diatas, peneliti ingin meneliti tentang Rekonstruksi Peranan Pers terhadap Kasus Pidana Korupsi di Indonesia Berbasis Nilai Keadilan. Rekontruksi terhadap peranan pers pada Pasal 3 dan Pasal 6 untuk lebih dipertegas, khususnya pada Pasal 6 point (e) mengenai memperjuangkan keadilan dan kebenaran.

\section{B. Metode Penelitian}

Metode pendekatan yang digunakan dalam penelitian ini adalah pendekatan yuridis sosiologis (sociolegal research) dan juga pendekatan perundang-undangan (statute approach). Pendekatan yuridis sosiologis dipergunakan dalam penelitian ini karena dalam penelitian ini lebih banyak mengkaji persepsi hukum dan perilaku subyek penelitian yaitu para penyidik dan penuntut umum perikanan, serta masyarakat pada umumnya terhadap efektifitas berlakunya hukum positif perikanan di masyarakat. Data yang diperlukan dapat diperoleh dengan teknik pengamatan (observasi), wawancara ataupun penyebaran angket.

Sedangkan pendekatan perundangundangan dilakukan dengan tujuan untuk mengalisis peraturan perundang-undangan dibidang perikananan, terutama yang berkaitan dengan penerapan norma hukum yang mengatur tentang perlindungan hukum pengelolaan perikanan di Indonesia.

\section{Hasil Penelitian dan Pembahasan}

Media massa adalah suatu jenis komunikasi yang ditujukan kepada sejumlah khalayak yang tersebar, heterogen dan anomim melewati media cetak atau elektronik, sehingga pesan informasi yang sama itu dapat diterima secara serentak dan sesaat ${ }^{3}$. Pemanfaatan media massa artinya penggunaan berbagai bentuk media massa, baik cetak maupun elektronik untuk tujuan tertentu ${ }^{4}$. Secara umum, media massa mempunyai fungsi sebagai media informasi, pendidikan, hiburan dan kontrol sosial. Hal ini seperti dirumuskan dalam Pasal 3 ayat (1) dan ayat (2) Undang-Undang No. 40 Tahun 1999 tentang Pers, yaitu Fungsi Pers Nasional adalah sebagai media informasi, pendidikan, hiburan dan kontrol sosial, serta dapat berfungsi sebagai lembaga ekonomi ${ }^{5}$.

Fungsi kontrol sosial dari pers tersebut selanjutnya dijelaskan dalam Penjelasan Umum Undang-Undang Pers No. 40 Tahun 1999 tentang Pers, yang antara lain dinyatakan, bahwa untuk melaksanakan kontrol sosial sangat penting pula untuk mencegah terjadinya penyalahgunaan kekuasaan baik korupsi, kolusi, nepotisme, maupun akan penyelewengan dan penyimpangan lainnya ${ }^{6}$.

Berdasarkan perumusan fungsi pers atau media massa dalam Undang-Undang Pers di atas dapat diketahui bahwa fungsi dari pers atau media massa adalah sebagai media informasi, pendidikan, hiburan dan kontrol sosial. Dalam kaitan hubungannya dengan pemanfaatan media massa dalam penanggulangan tindak pidana korupsi, maka fungsi media massa di sini terutama sebagai media informasi, pendidikan dan kontrol sosial.

Dengan demikian dapat disimpulkan bahwa dalam pemanfaatan media massa baik cetak maupun elektronik, kaitannya untuk penegakan hukum tindak pidana korupsi antara lain berupa: Informasi atau berita-berita aktual dari berbagai isu yang berkaitan dengan praktik-praktik korupsi;

3 Deddy Mulyana, 2008, Komunikasi Massa Kontroversi, Teori, dan Aplikasi, Bandung: Widya Padjadjaran, Bandung.

4 http://re-searchengines.com/mangkoes6-04-2. html diakses tanggal 31 Agustus 2010.

5 Lihat Pasal 3 ayat (1) dan ayat (2) UndangUndang Nomor 40 Tahun 1999 Tentang Pers.

6 Lihat Penjelasan Umum Undang-Undang Nomor 40 Tahun 1999 Tentang Pers. 
Pengungkapan dan peliputan kasus-kasus korupsi dan modus operandi dari praktikpraktik korupsi; Mengangkat berbagai berita korupsi di berbagai level pemerintahan dan lembaga penegak hukum secara objektif; Pemberitaan penanganan akan tindak pidana korupsi oleh penegak hukum sejak penyidikan, penuntutan, pengadilan dan pemasyarakatan.

Fungsi kontrol sosial media massa terkait dengan penanggulangan tindak pidana korupsi disini antara lain dapat berupa pemantauan terhadap pengungkapan kasuskasus korupsi yang ditangani oleh penegak hukum yang dimulai sejak penyidikan, penuntutan, pengadilan dan pemasyarakatan.

Peranan pers atau juga media massa sebagaimana dirumuskan dalam Pasal 6 Undang-Undang Pers No. 40 Tahun 1999 tentang Pers disebutkan bahwa Pers Nasional akan melaksanakan peranan sebagai berikut: Untuk memenuhi hak masyarakat untuk mengetahui; Menegakkan nilai-nilai dasar demokrasi, mendorong mewujudkan supremasi hukum, dan Hak Asasi Manusia, serta menghormati kebhinekaan; Mengembangkan pendapat umum yang berdasarkan informasi yang tepat, akurat dan benar; Melakukan pengawasan, kritik, koreksi dan juga saran terhadap hal-hal yang berkaitan dengan kepentingan umum; Memperjuangkan keadilan dan kebenaran ${ }^{7}$.

Melihat peranan yang strategis dari pers atau media massa tersebut, maka G.P. Hoefnagels mencantumkan pers atau media massa (mass media) ini sebagai salah satu unsur yang harus ada dalam kebijakan penanggulangan kejahatan atau juga criminal policy. Seperti digambarkan oleh Hoefnagels pada skema berikut ini:

\section{Bagan Ruang Lingkup \\ Penanggulangan Kejahatan (Criminal Policy)}

Sumber : G.P. Hoefnagels, 1969.

7 Pasal 6 Undang-Undang Pers No. 40 Tahun 1999 tentang Pers.
Dari skema di atas dapat diketahui bahwa fungsi dari media massa dalam kerangka politik kriminal menurut Hoefnagels ditujukan untuk mempengaruhi pandanganpandangan masyarakat tentang kejahatan dan pemidanaan atau influencing view of society on crime and punishment. Peranan media massa dalam kerangka politik kriminal ini menurut Hoefnagels disejajarkan dengan upaya-upaya politik kriminal yang lain yaitu Criminal Law Application (Practical Criminology) yaitu penanggulangan kejahatan dengan sarana hukum pidana dan juga Prevention Without Punishment yaitu penangulangan kejahatan melalui sarana di luar hukum pidana.

Sehubungan dengan pendapat Hoefnagels bahwa fungsi media massa adalah untuk mempengaruhi pandanganpandangan masyarakat tentang kejahatan dan pemidanaan maka apabila dihubungkan dengan fungsinya dalam hal penanggulangan tindak pidana korupsi, media massa di sini diharapkan dapat untuk berpengaruh terhadap pandangan masyarakat tentang pengetahuan, perasaan atau keyakinan dan perilaku partisipatif masyarakat dalam penanggulangan tindak pidana korupsi.

Media massa sebagai suatu sarana yang bersifat non-penal dapat diperankan juga sebagai salah satu upaya penegakan hukum tindak pidana korupsi. Sebagai sarana non-penal media massa dapat pula digunakan sebagai pendorong bekerjanya sarana penal agar menjadi lebih efektif.

Peranan media massa di dalam menyampaikan informasi kepada masyarakat tentang penanganan penegakan hukum tindak pidana korupsi, agar dapat diketahui secara cepat oleh masyarakat, tidak perlu dilakukan dengan komunikasi tatap muka. Dalam hal ini aparat penegak hukum (Kepolisian, Kejaksaan, Pengadilan, Lembaga Pemasyarakatan) cukup untuk melakukan press release ke media atau mengundang wartawan untuk jumpa pers, sehingga dalam waktu singkat informasi itu akan tersebar luas ke tengah masyarakat.

Dilihat dari dimensi media massa, maka informasi yang disampaikan oleh aparat 
sistem peradilan pidana (SPP) mengenai materi penanganan kasus korupsi yang diterima masyarakat ini diharapkan mempunyai efek yang positif dalam penanggulangan tindak pidana korupsi.

Efek atas adanya pemberitaan akan penanganan tindak pidana korupsi yang disampaikan oleh aparat sistem peradilan pidana ini yaitu dengan adanya efek kognitif, afektif, dan konatif. Efek kognitif meliputi peningkatan akan kesadaran, belajar, dan tambahan pengetahuan. Efek afektif itu berhubungan dengan emosi, perasaan, dan attitude atau sikap. Sedangkan efek konatif berhubungan dengan perilaku dan niat untuk dapat melakukan sesuatu menurut cara tertentu ${ }^{8}$. Media massa sebagai kekuatan strategis dalam menyebarkan informasi itu merupakan salah satu otoritas sosial yang berpengaruh dalam membentuk sikap dan norma sosial daripada suatu masyarakat. Pengaruh media massa terhadap perilaku dan sikap masyarakat, dipelopori oleh DeFleur yang selalu mengembangkan teori tentang efek. Pengembangan awal yang telah dilakukan oleh DeFleur adalah dengan memperhitungkan variabel psikologis dalam proses efek, maka selanjutnya dia mengembangkan teorinya dengan memasukan variabel norma budaya kedalam efek dari media massa. Teori yang disebut norma budaya (Cultural Norms) ini beranggapan bahwa media tidak hanya memiliki efek langsung terhadap individu, tetapi juga mempengaruhi kultur, pengetahuan kolektif dan juga norma serta nilai-nilai dari suatu masyarakat. Media massa telah dapat menghadirkan seperangkat citra atau images, gagasan dan evaluasi dari mana khalayak dapat memilih dan juga menjadikan acuan bagi perilakunya. Misalnya saja dalam hal perilaku pemberian hadiah kepada pejabat, media massa memberikan suatu pandangan komulatif mengenai apa yang dianggap normal atau juga wajar dan yang tidak wajar ${ }^{9}$.

Peran media massa dalam pemberantasan korupsi antara lain dikemukakan pula oleh anggota Divisi

8 www.subscrib.com, diakses 30 Agustus 2015.

9 www.subscrib.com
Investigasi Indonesian Corruption Watch (ICW), Tema S. Langkun, menjelaskan media memiliki tiga peran serta yang vital dalam pemberantasan korupsi yaitu mengungkap kasus korupsi melalui pemberitaan, melakukan investigasi terhadap kasus korupsi dan melakukan kontrol dan pengawasan terhadap sebuah isu tindak pidana korupsi ${ }^{10}$ Dari beberapa pendapat tersebut di atas diketahui bahwa media massa mempunyai peranserta yang vital dan strategis dalam penanggulangan tindak pidana korupsi, karena media massa dapat mengungkap kasus korupsi melalui pemberitaan dan melakukan kontrol atau pengawasan terhadap berjalannya pengungkapan kasus korupsi oleh penegak hukum.

Kontrol yang dilakukan oleh media massa terhadap aparat penegak hukum (sistem peradilan pidana) yaitu dengan cara meliput atau memberitakan proses pelaksanaan penanganan dan penanggulangan tindak pidana korupsi. Materi yang diliput atau diberitakan ini akan sekaligus mempunyai fungsi dan juga peran yang strategis dalam politik kriminal atau criminal policy, khususnya penanggulangan kejahatan (tindak pidana korupsi) melalui sarana non-penal. Disini penulis melihat bahwa materi atau isi pemberitaan media massa merupakan salah satu bentuk dari upaya non-penal untuk menanggulangi kejahatan. Perlunya dilakukan upaya nonpenal ini karena adanya alasan bahwa masih diragukannya atau dipermasalahkannya efektivitas sarana penal dalam mencapai tujuan politik kriminal ${ }^{11}$.

Dilihat dari suatu dinamika agenda, maka tampak diketahui bahwa pemanfaatan media massa untuk penanggulangan tindak pidana korupsi, sekaligus merefleksikan adanya interaksi di antara agenda media, agenda pengambil kebijakan, dan agenda publik. Adanya interkasi ini terlihat dengan

10 Suara Merdeka, Edisi Rabu 13 Januari 2010 : hlm.12.

11 Barda Nawawi Arif, Bunga Rampai Kebijakan Hukum Pidana, Citra Aditya Bakti, Bandung, 1996, hal.23. 
adanya pertanggungjawaban pers atas pemberitaan yang mana menyangkut dengan masyarakat tidak akan dapat dilepaskan keterkaitannya dengan interaksi antara pers dengan pemerintah. Menurut Samsul Wahidin, dengan asumsi pemerintah sebagai instansi yang juga berkedudukan sebagai pembina kehidupan pers besar pengaruhnya terhadap corak kehidupan pers di negara bersangkutan. Bahkan dalam sistem pers di Indonesia sering dikemukakan hubungan itu juga tidak terlepas dengan masyarakat sebagai bagian dari interaksi yang dituangkan dalam cita-cita terwujudnya interaksi antara pemerintah, pers dan masyarakat ${ }^{12}$

Dalam penanggulangan tindak pidana korupsi, dinamika agenda dari ketiga sub-sistem (Pemerintah, Media, Masyarakat) proses interakasi yang diperankan masing-masing berkedudukan sejajar, yaitu adanya keinginan bersama untuk dapat menanggulangi tindak pidana korupsi. Pemerintah yang dijalankan oleh aparat sistem peradilan pidana, media, dan masyarakat mempunyai keinginan kuat untuk memberantas atau menanggulangi tindak pidana korupsi.

Landasan pokok yang mana harus dipergunakan dalam interkasi ini adalah kepercayaan atau saling percaya antara pihak pers dengan pemerintah (sistem peradilan pidana) secara timbal balik khususnya yang datang dari pemerintah. Atas dasar kepercayaan ini, yang disajikan oleh pres tidak dilihat dalam perspektif negatif tetapi secara proporsional mengedepankan pula aspek positifnya ${ }^{13}$

Berdasarkan pada landasan pokok di atas, maka hendaknya reaksi aparat sistem peradilan pidana dalam menanggapi materi pemberitaan media massa mengenai penanganan tindak pidana korupsi tidak perlu ditanggapi secara reaktif negatif, melainkan harus dilihat sebagai bentuk positif bahwa kinerja atau kerjanya terpantau publik melalui

12 Wahidin, Samsul, 2006, Hukum Pers, Pustaka Pelajar, Yogyakarta, hal.50.

13 Wahidin, Samsul, 2006, Hukum Pers, Pustaka Pelajar, Yogyakarta, hal.51. media massa.

Di sini media bukan saja sebagai sumber informasi publik, melainkan juga sebagai faktor pendorong atau trigger untuk dapat mengoptimalkan fungsi dan peran instansi penegak hukum (sistem peradilan pidana) dalam penanggulangan tindak pidana korupsi.

Faktor pendorong ini didukung oleh kelebihan media massa itu sendiri yaitu Pertama, media massa mempunyai daya jangkau yang luas. Pemberitaan akan penegakkan hukum melalui media massa akan mempunyai daya jangkau atau coverage yang sangat luas dalam menyebarluaskan informasi penanganan tindak pidana korupsi, akan mampu untuk melewati batas wilayah (geografis), kelompok umur, jenis kelamin dan juga sosial-ekonomi-status (demografis) dan perbedaan paham dan juga orientasi psikografis. Dengan begitu, akan menghasilkan umpan balik bagi aparat penegak hukum, pelaku tindak pidana korupsi maupun keluarganya.

Bagi aparat penegak hukum melahirkan dampak psikologis yaitu dari bekerjanya terpantau oleh publik. Bagi terdakwa tindak pidana korupsi atau keluarganya akan menimbulkan efek malu, karena kejahatannya diketahui oleh publik. Kedua, kemampuannya melipat-gandakan pesan atau multiplier of message yang luar biasa. Suatu peristiwa hukum bisa dilipatgandakan pemberitaannya sesuai jumlah eksemplar koran, tabloid, dan majalah yang tercetak; juga bisa diulang-ulang penyiarannya sesuai kebutuhan. Alhasil, pelipatgandaan ini menimbulkan dampak yang sangat besar di tengah khalayak. Ketiga, setiap media bisa mewacanakan sebuah peristiwa hukum sesuai pandangannya masing-masing, tentu saja dengan fungsi agenda setting yang dimilikinya, media memiliki kesempatan yang sangat luas (bahkan hampir tanpa batas) untuk memberitakan kasus tindak pidana korupsi, sehingga agenda media pararel dengan agenda publik, dan dampaknya akan semakin kuatlah peran media dalam membentuk opini publik. 
D. PENUTUP

\section{Kesimpulan}

Tindak pidana korupsi selalu menarik perhatian media massa sebagai bahan liputan. Hal ini terjadi karena adanya 2 (dua) faktor yang saling berkaitan. Pertama, dewasa ini hukum berada di era teknologi informasi dan komunikasi sehingga hampir mustahil bahwa kehidupan hukum itu dipisahkan dari media massa. Konsekuensinya perlu peran aktif dari aparat penegak hukum untuk melibatkan media massa dalam penanggulangan kejahatan termasuk tindak pidana korupsi. Kedua, hukum dalam bentuk tingkah laku dan pernyataan para aktor publik lazimnya selalu mempunyai nilai berita sekalipun peristiwa hukum itu bersifat rutin belaka, seperti pembunuhan, pencurian. Apalagi jika peristiwa hukum itu bersifat luar biasa seperti kejahatan kerah putih dan lain sebagainya.

\section{Saran}

Liputan peristiwa hukum cendrung lebih rumit ketimbang reportase di bidang kehidupan lainnya. Pada satu pihak, liputan hukum memiliki dimensi pembentukan opini publik atau public opinion, baik yang diharapkan oleh para penegak hukum maupun oleh wartawan. Putusan pemidanaan terhadap pelaku tindak pidana korupsi diharapkan mempengaruhi sikap khalayak mengenai perbuatan yang dilakukan oleh terdakwa. Dalam komunikasi politik, aspek pembentukan opini ini memanglah menjadi suatu tujuan utama, karena hal ini akan mempengaruhi pencapaian-pencapaian tujuan pidana.

\section{DAFTAR PUSTAKA}

\section{- Buku-buku}

Andi Hamzah, 2005, Perbandingan Pemberantasan Korupsi di Berbagai Negara, Jakarta, Sinar Grafika.

Barda Nawawi, 1996, Bunga Rampai Kebijakan Hukum Pidana, Bandung, Citra Aditya Bakti. Deddy Mulyana, 2008, Komunikasi Massa Kontroversi, Teori, dan Aplikasi, Bandung: Widya Padjadjaran.

Djaja Ermansyah, 2013, Memberantas Korupsi Bersama KPK, Jakarta, Sinar Grafika. Jan Remmelink, 2003, Hukum Pidana, Jakarta, Jakarta, Gramedia Pustaka Utama. Jawade Hafidz, 2013, Korupsi Dalam Perspektif Hukum Administrasi Negara, Jakarta, Sinar Grafika. Jakarta.

Jeremy Pope, 2007, Strategi Memberantas Korupsi,Jakarta, Yayasan Obor Indonesia. Peter Hoefnagels, 1969, The Other Side of Criminology. An Inversion of the Concept of Crime, Kluwer-Deventer: Professor of Criminologi Roterdam University

Wirjono Prodjodikuro, 1969, Asas-asas Hukum Pidana di Indonesia, Bandung, Eresco. Zulkifli Noor, 2013, Deklarator Indonesia Seharusnya., Bandung 26 juni 2013.

\section{- Peraturan Perundang-undangan}

Undang-Undang Nomor 31 Tahun 1999 Tentang Pemberantasan Tindak Pidana Korupsi

Undang-Undang Nomor 40 Tahun 1999 Tentang Pers. 